\title{
AS ROCHAS GRANULITICAS DA FAIXA PARAÍBA DO SUL
}

\author{
MARCOS AURÉLIO FARIAS DE OLIVEIRA*
}

\begin{abstract}
Granulitic and migmatitic rocks of the Paraiba do Sul granulitic terrains are petrographically and structurally characterized. Charnockites, enderbites and two pyroxene granulites are described. Blastomilonitic textures are widespread all over the area. All studied rocks are strongly folded and deformed, showing transposition foliation, boudinage and conspicuous metamorphic banding. The granulites belong to the Juiz de Fora Complex, and are considered of Archean ages, with a polimetamorphic evolution.
\end{abstract}

INTRODUÇÃO As rochas granulíticas sempre mereceram atenção especial por parte dos petrólogos de todo o mundo, tendo em vista suas características mineralógicas e texturais peculiares. Nos últimos 20 anos, porém, as pesquisas em áreas de alto grau metamórfico intensificaram-se, pois se observou que a compreensão dos processos geradores da crosta inferior arqueana está diretamente ligada ao conhecimento da evolução geológica e petrográfica dessas rochas.

Numerosos modelos evolucionais têm sido propostos para explicar a' gênese dos granulitos e algumas feiçð̌es registram-se universalmente. Entre elas, citam-se as idades superiores a $2500 \mathrm{~m}$.a., temperaturas de formação entre $700^{\circ} \mathrm{C}$ e $1000^{\circ} \mathrm{C}$, e empobrecimento em elementos litófilos, principalmente $\mathrm{Rb}, \mathrm{K}$ e $\mathrm{U}$.

No Brasil, rochas dessa natureza são abundantes no embasamento pré-cambriano e situam-se principalmente nos cinturôes granulíticos Atlântico e Goiás (Wernick et al., 1979). Dentro do cinturåo Atlântico, numa extensa faixa que se estende principalmente ao longo do vale do Rio Paraíba do Sul por mais de $250 \mathrm{~km}$, com uma largura média de $60 \mathrm{~km}$, ocorrem rochas charnockíticas e granulíticas que se associam a gnaisses e migmatitos bandados, com intercalações subordinadas de mármores e quartzitos.

Parte desse cinturão é estudado no presente trabalho, em área que se estende de sudoeste para nordeste, tendo como referência principal o alongamento do Rio Paraiba do Sul, que corre em sua porção central. Como limite oeste, pode ser considerada a linha que une as cidades de Teresópolis, Três Rios e Juiz de Fora; e, como limite leste, a linha que une as cidades de Itaperuna e Carangola (Fig. 1). A base geológica dessa área, lançada na Fig. 1, foi compilada, com modificaçð̌es da Folha do Rio de Janeiro, da Carta Geológica do Brasil ao Milionésimo (1978) e do Mapa Geológico do Estado do Rio de Janeiro (1977). Na Fig. 1 săo representadas também as amostras com análise química e outras referidas no texto.

O objeto de nossa pesquisa são as rochas charnockíticas e granuliticas existentes na porção central do mapa da Fig. 1. Todo o trabalho inicial procurou caracterizar geológica e petrograficamente apenas as litologias granulíticas, mas verificou-se ser impossível um melhor conhecimento da evolução dessas rochas sem incluir também estudos das litologias que ocorrem ao norte (migmatitos e granitos de idade arqueana; Complexo Barbacena) e ao sul (migmatitos, gnaisses, granitóides e gránitos de idade Brasiliana; Delhal et al., 1969). Desta forma, as observaçðes de campo e os perfis geologicos executados visaram, principalmente, à obtenção de dados li- tológicos, estruturais e, posteriormente, petrográficos e químicos que permitissem uma melhor compreensão das relaçðes entre essas litologias e, em particular, dos granulitos' e charnockitos.

O estudo petrográfico pormenorizado das amostras coletadas, somado às observaçðes de campo e à análise da bibliografia disponível, permitiu a caracterização das seguintes unidades litológicas, dispostas de norte para sul (Fig. 1):

1. Migmatitos heterogêneos de estrutura bandada e do. brada, ricos em encraves e intercalaçðes de anfibolitos. As partes claras são granodioríticas.

2. Rochas charnockíticas e granulitos mais ou menos cataclásticos, às vezes blastomiloníticos. Estruturas bandadas são vistas assumindo, localmente, aspecto migmatítico, com as porçðes mais ácidas charnockíticas envolvendo ou corroendo as porções mais básicas (enderbíticas ou mesmo gábricas). Estão presentes também em toda a faixa granada gnaisses (kinzigitos), principalmente nas proximidades de Juiz de Fora.

3. Migmatitos de estruturas variadas: mais homogêneas (embrechíticas, schlieren ou nebulíticas) até fortemente bandadas ou agmatíticas (schollen), também intensamente deformadas, incluindo com frequência boudins ou xenólitos de rochas anfibolíticas, cálcio-silicáticas e mais raramente charnockíticas. As porçðes mais homogêneas de composição granítica podem variar para tipos mais dioríticos, localmente. Quartzitos constituem pequenos corpos embutidos nesse conjunto.

4. Gnaisses e granulitos finamente bandados (fitados), blastomiloníticos, intensamente dobrados, exibindo foliação vertical resultante de transposição de foliação anterior, incluindo boudins de rocha anfibolítica, de granulitos básicos e de tipos cálcio-silicáticos. Intercalaçðes de quartzitos, mármores e rochas cálcio-silicáticas.

5. Gnaisses e migmatitos bandados, de composição granítica, passando localmente a granodiorítica ou diorítica, intensamente dobrados com boudins ou xenólitos de rochas cálcio-silicáticas, anfibolitos e mais raramente de charnockitos.

6. Migmatitos, gnaisses granitoides e granitos. As estruturas nos gnaisses e migmatitos são por vezes bandadas, predominando, no entanto, os tipos nebulíticos; comuns também são as estruturas tipo schlieren. São ricos em xenólitos e cortados por corpos aplíticos e pegmatíticos de dimensðes variadas. Os granitos exibem coloração cinza-claro e são grossos.

As denominaçð̃es utilizadas para essas unidades são: Complexo Barbacena para a Unidade 1 e Complexo Juiz de

\footnotetext{
* Instituto de Geociências e Ciências Exatas, Universidade Estadual Paulista "Júlio de Mesquita Filho", caixa postal 178, CEP 13500, Rio Claro, São Paulo
} 


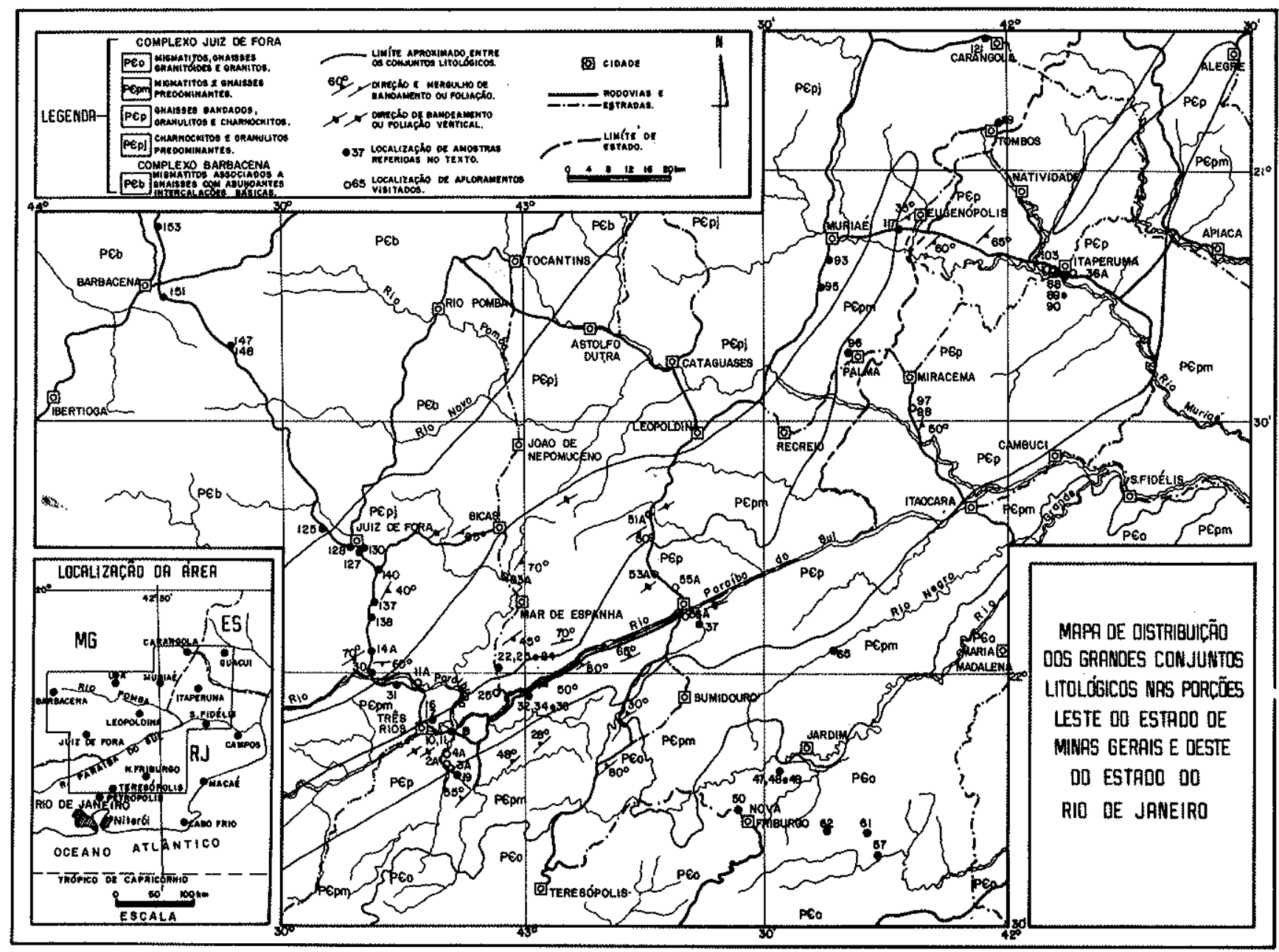

Figura I - Mapa de distribuiçáo dos grandes conjuntos litologicos nas porçðes leste do Estado de Minas Gerais e oeste do Estado do Rio de Janeiro

Fora para as demais unidades (Hasui e Oliveira, no prelo). Dentro do Complexo Juiz de Fora, trataremos a Unidade 2 como Faixa de Juiz de Fora, as unidades 3, 4 e 5, como a Faixa Paraíba do Sul e a Unidade 6, como Faixa Serra dos Órgãos.

COMPLEXO BARBACENA As rochas da unidade litológica 1 constituem o Complexo Barbacena de idade arqueana (Cordani et al., 1973). Correspondem a migmatitos de estrutura bandada e dobrada, incluindo grande quantidade de rochas básicas sob a forma de blocos ou boudins; granitos ou granodioritos formam o leucossoma desses migmatitos. A mineralogia essencial dos tipos claros é dada por quartzo, microclínio intersticial ou na forma de porfiroblastos, pertita como porfiroclastos, plagioclásio tipo oligoclásio-andesina, além de biotita parda e moscovita que se cristalizam sobre os demais minerais. Nos tipos mesocráticos, destacam-se o plagioclásio (andesina) saussuritizado, a hornblenda verde-parda e a biotita marrom. As intercalaçð̃es básicas, constituídas por hornblenda verde-parda, clinopiroxênios e plagioclásio (andesina-labradorita), correspondem petrograficamente a anfibolitos ou granulitos.

A textura dessas litologias é predominantemente cataclástica a milonítica e até mesmo blastomilonítica. Feldspato potássico pertítico e plagioclásio saussuritizado constituem porfïroclastos, enquanto quartzo, microclínio e plagioclásio constituem a matriz mais ou menos granoblástica em função da intensidade de recristalização (Fotomicrografia 1).

Aspecto marcante dessas rochas é o processo de saussuritização dos plagioclásios, que aumenta para o norte à medida que penetramos os migmatitos, a tal ponto que nas proximidades de Barbacena as rochas graníticas apresentam os plagioclásios quase que totalmente substituídos por epídoto e sericita. Nessas rochas recristaliza também, dentro do mesmo processo, biotita verde.

COMPLEXO JUIZ DE FORA Faixa Juiz de Fora Também de idade arqueana (Cordani et al., 1973), são as rochas charnockíticas e granulitos que aparecem imediatamente ao sul desses migmatitos e que se estendem por mais de uma centena de quilómetros, com larguras médias de $20 \mathrm{~km}$. Tais rochas, enquadradas na "Série Juiz de Fora" por Ebert (1957), são muito semelhantes às que ocorrem ao longo do Rio Paraíba do Sul, sendo reunidas aqui sob a denominação de Complexo Juiz de Fora. A idade de $2,8 \mathrm{Ga}$, ou mesmo superior, para essas litologias é indicada no trabatho de Cordani et al. (1973) por algumas amostras coletadas nas proximidades de Juiz de Fora e que fornecem pontos acima da isócrona transamazônica, dispondo-se aproximadamente no mesmo alinhamento das amostras arqueanas. 


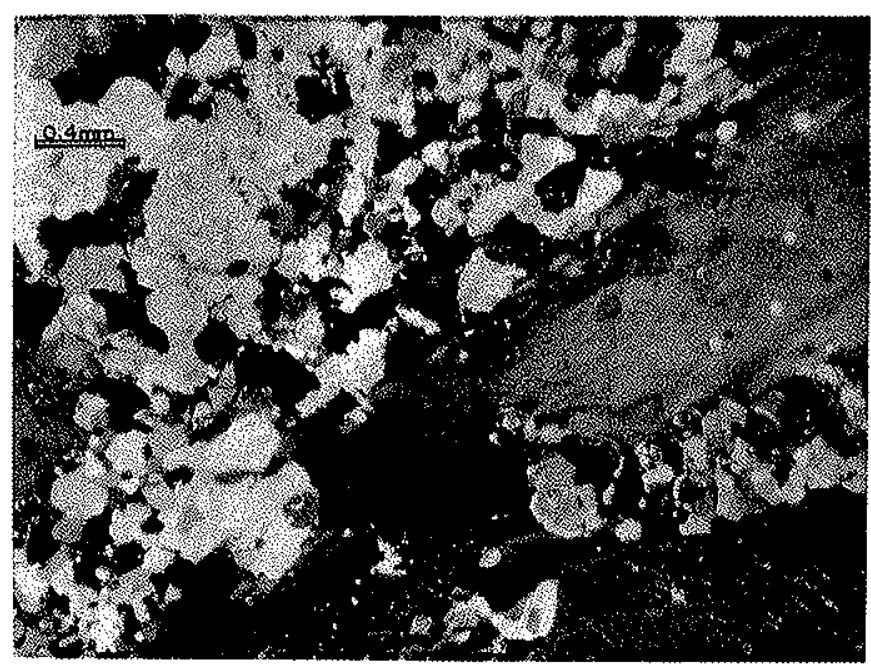

Fotomicrografia 1-Amostra 147. Porfiroclastos de feldspato potássico pertiticos, rodeados por mosaico granoblástico de quartzo e microclínio. Nicóis cruzados

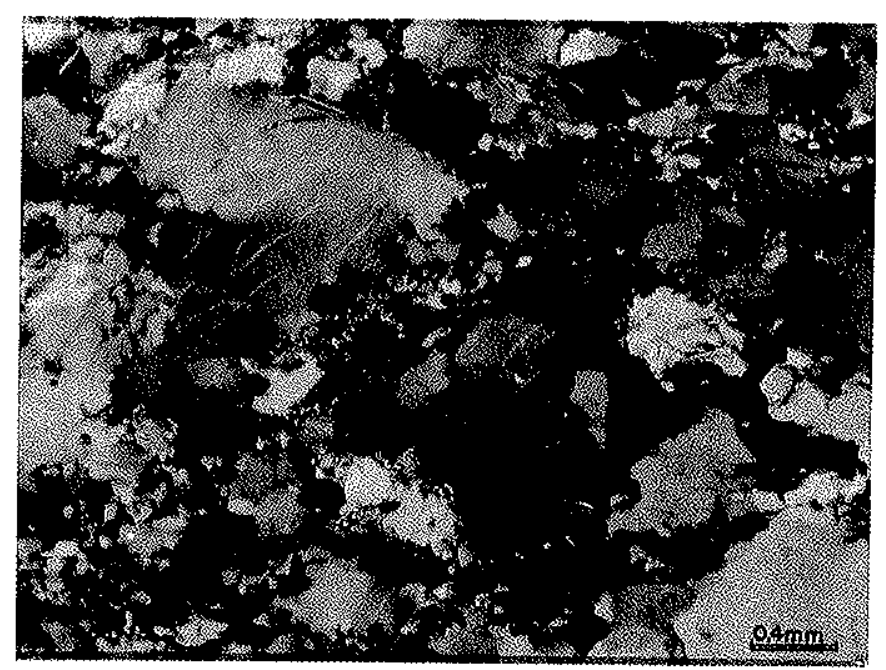

Fotomicrografia 2 - Amostra 140. Charnockito cataclastico. Porfiroclastos de feldspato potássico pertítico e plagioclásio. Recristalização incipiente da matriz. Nicóis cruzados

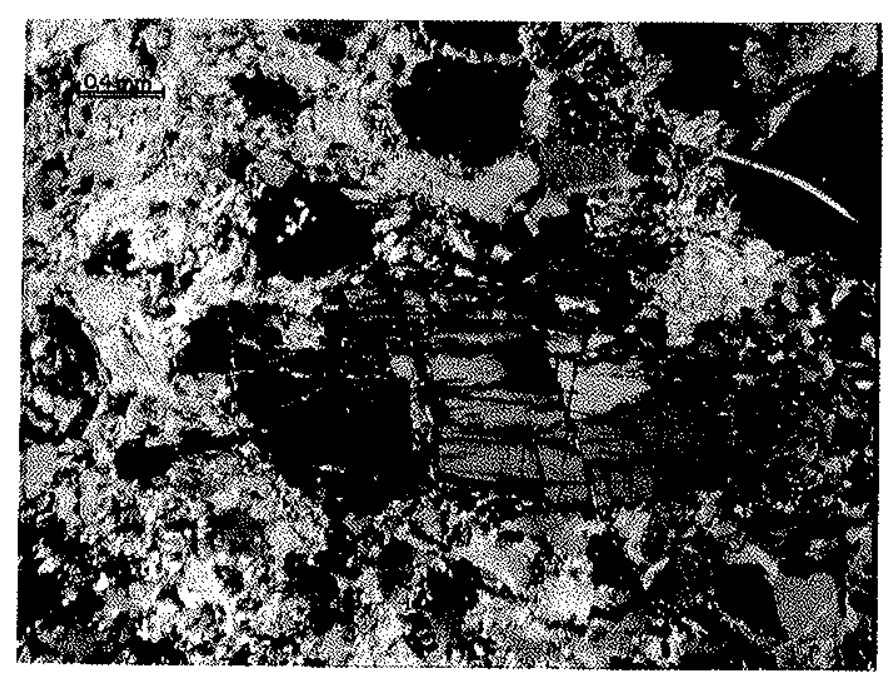

Fotomicrografia 3 - Amostra 130. Porfiroclastos de hiperstênio fraturados e parcialmente substituidos por biotita. Nicois cruzados
As estruturas presentes nessas rochas são principalmente as bandadas, intercalando-se bandas de granulação fina, cinza-claras, em bandas charnockíticas, esverdeadas, ou bandadas pretas de tipos enderbíticos e até mais básicos. Mostramse intensamente dobradas, assumindo essas dobras, às vezes, $o$ aspecto difuso como o que se observa em migmatitos, sendo que, neste caso, as porções mais claras, charnockíticas, invadem ou envolvem as partes mais escuras, em geral enderbíticas.

Os tipos petrográficos encontrados nessa associação litológica pertencem principalmente à série charnockítica $\mathrm{e}$ têm caráter plutônico. São representados por hiperstênio granitos (charnockitos), hiperstênio granodioritos, hiperstênio tonalitos (enderbitos) e noritos, denominaçzes baseadas na proposta de nomenclatura de Streckeisen (1974). A textura primária exibida por eles é granular hipidiomórfica, mascarada quase sempre pela cataclase e recristalização.

O processo de cataclase e recristalização é intenso e generalizado, e transforma essas rochas em milonitos e granulitos blastomiloníticos, fato também observado e descrito na região de São Fidélis por Costa e Marchetto (1978). Ortoclásio pertítico, plagioclásio e hiperstênio são os porfiroclastos mais comuns. Quartzo exibe sempre forte estiramento, formando freqüentemente cordoes que separam mosaico granoblástico, quartzo-feldspático e de granulação mais fina. Nas amostras menos atingidas pela cataclase, nota-se apenas a formação de texturas em moldura com recristalização incipiente das partes quebradas (Fotomicrografia 2).

Minerais característicos dessas rochas de catazona são os ortopiroxênios que aparecem quase sempre como restos envolvidos por hornblenda ou biotita, ou como porfiroclastos fraturados e corroídos (Fotomicrografia 3). Não recristalizam na matriz granoblástica dos granulitos blastomiloníticos, aparecendo em seu lugar ou junto a seus restos fraturados, biotita parda ou hornblenda verde-amarelada. Quanto a esse aspecto, vale a pena ressaltar que a biotita sempre recristaliza numa derradeira fase, sendo só sucedida por moscovita e, às vezes, clorita, que parecem ser os últimos minerais secundários a se formar.

A associação de orto e clinopiroxênios em equilibrio merece destaque principalmente nos tipos enderbíticos, quando esses minerais ocorrem associados à hornblenda marrom. Granada aparece em pequenas quantidades em boa parte desses granulitos, destacando-se nos gnaisses de paragêneses kinzigíticas, onde ocorre também a sillimanita. Ocorrências notáveis desses gnaisses granatíferos estão localizadas nas proximidades da cidade de Juiz de Fora.

Faixa Paraíba do Sul A faixa que se segue logo ao sul é constituída, predominantemente, por migmatitos cinzentos (branco e preto), encerrando intercalaçðes de rochas charnockíticas e corpos granulíticos de dimensðes variadas, além de tipos cálcio-silicáticos, anfibolitos e quartzitos. As estruturas mais notáveis dessa litologia são as bandadas, estromatíticas, resultantes da transposição de foliação ou bandamento mais antigo, causada por uma fase de redobramento muito intensa (Fotos 1 e 2). Quando a transposição é total, o que acontece à medida que nos aproximamos do vale do Rio Paraíba do Sul, as rochas resultantes são gnaisses finamente bandados (bandamento centimétrico); neste caso, a forte deformação pode ser evidenciada pela presença de corpos boudinados ou intercalaçőes tectônicas de anfíbolitos, cálciosilicáticas e granulitos (Foto 3). Nas proximidades de Três Rios, essas feiçðes são ressaltadas no trabalho de Campanha (1981). 


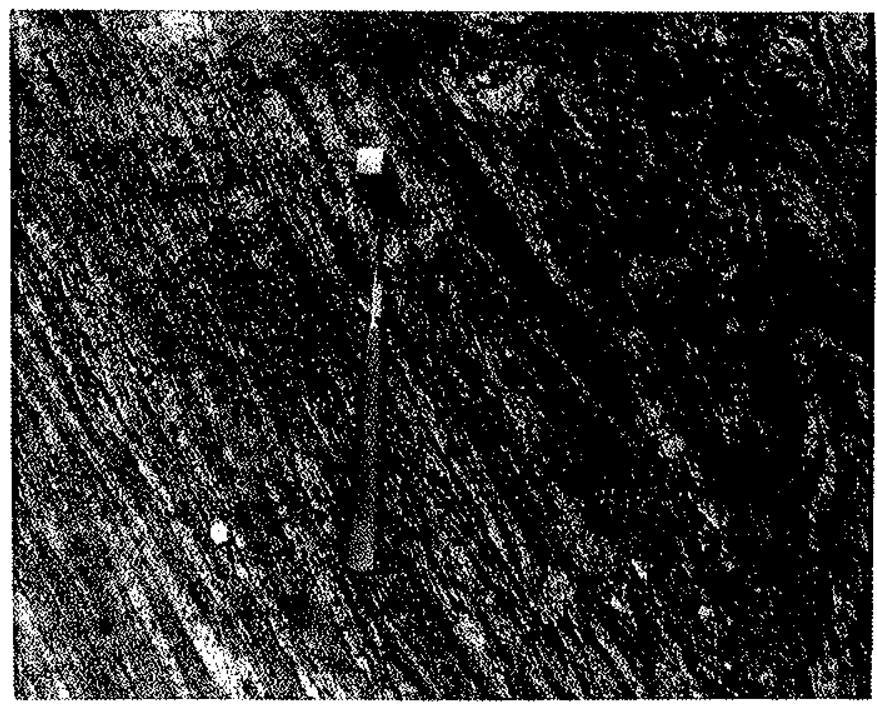

Foto 1 - Ponto 51. Migmatito cinzento, bandado e fortemente dotrado, com transposiģão da foliaçao

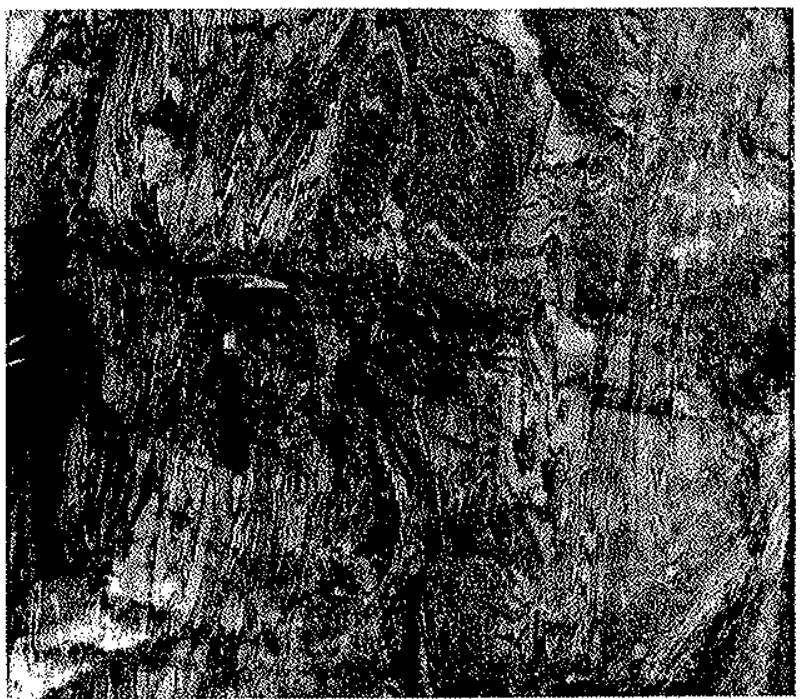

Foto 2 - Ponto 55. O mesmo migmatito cinzento com estrutura bandada, fortemente dobrado, com nitida foliaçáo de transposiçao

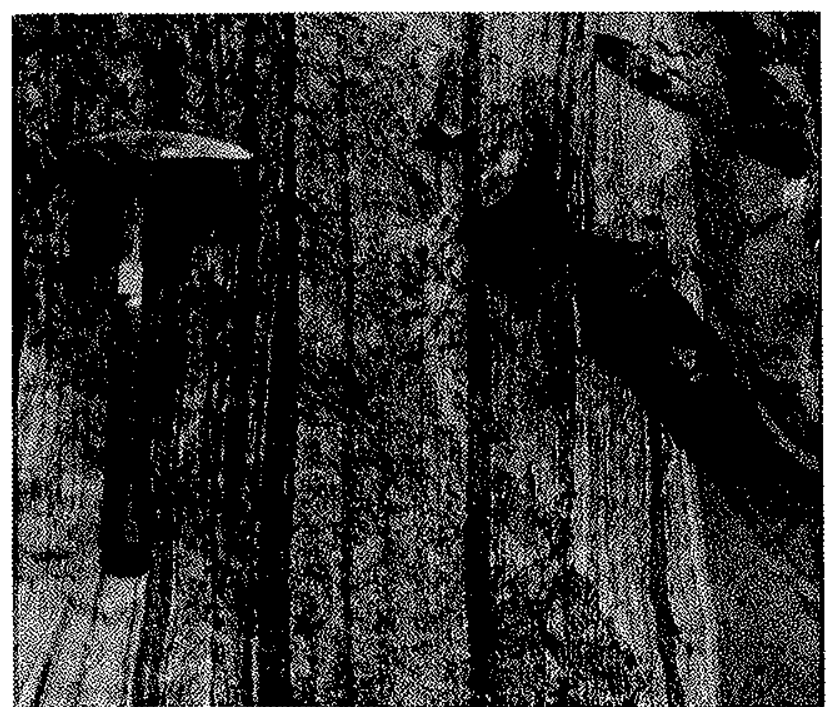

Foto 3 - Ponto 56. Gnaisse bandado, cuja estrutura resulta de fortes deformaçסes com transposição da antiga folią̧ão
Além dos tipos estromatíticos, encontram-se também extensas ocorrências de variedades mais homogêneas, embrechiticas, com estrutura schlieren ou mesmo nebulíticas, predominando as composiçðes graníticas, granodioríticas e menos comumente as dioríticas. São ricos em veios e bolsðes pegmatíticos ou aplíticos, róseos, concordantes ou discordantes da foliação, além de pequenos corpos arredondados de rocha cálcio-silicática ou anfibolito. Esses corpos arredondados, em muitos afloramentos, são interpretados como verdadeiros xenólitos, envolvidos numa fase mais granítica ou granodiorítica (Foto 4). Em outros locais, no entanto, parecem corresponder mais a corpos rompidos tectonicamente (boudins), numa fase de intensa deformação (Foto 5). Estruturas agmatíticas ou schollen foram observadas em diversos afloramentos.

A característica textural mais marcante dessas rochas é a cataclase com recristalização, levando à formação de tipos blastomiloníticos. A diferença em relação aos granulitos reside numa recristalização de microclínio pós-deformação, levando a matriz granoblástica a assumir caráter granítico, que nas rochas da Faixa de Juiz de Fora não é comument observada.

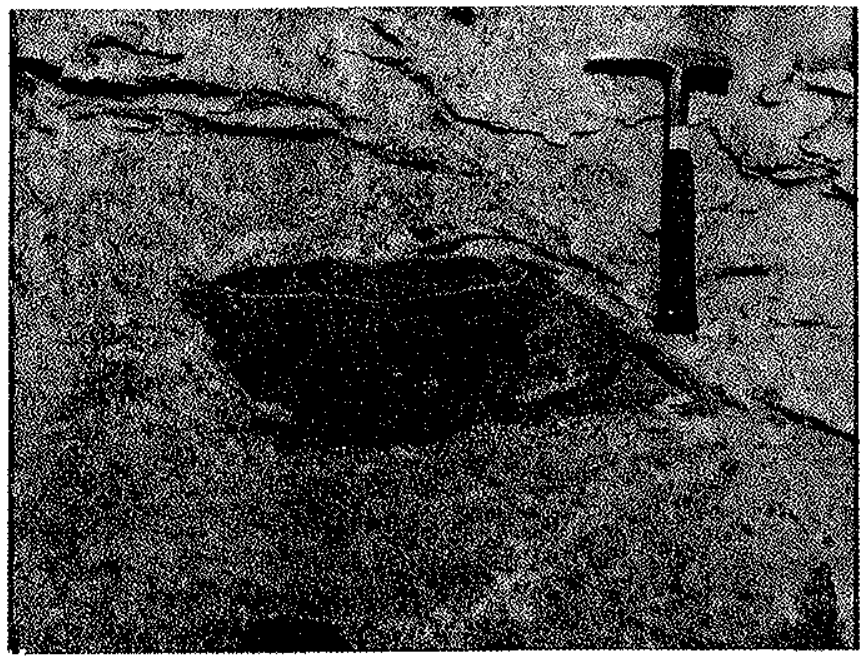

Foto 4 - Ponto 83. Magmatito cinzento nebulitico, conten "xenólitos" de anfibolitos e rochas cálcio-silicáticas

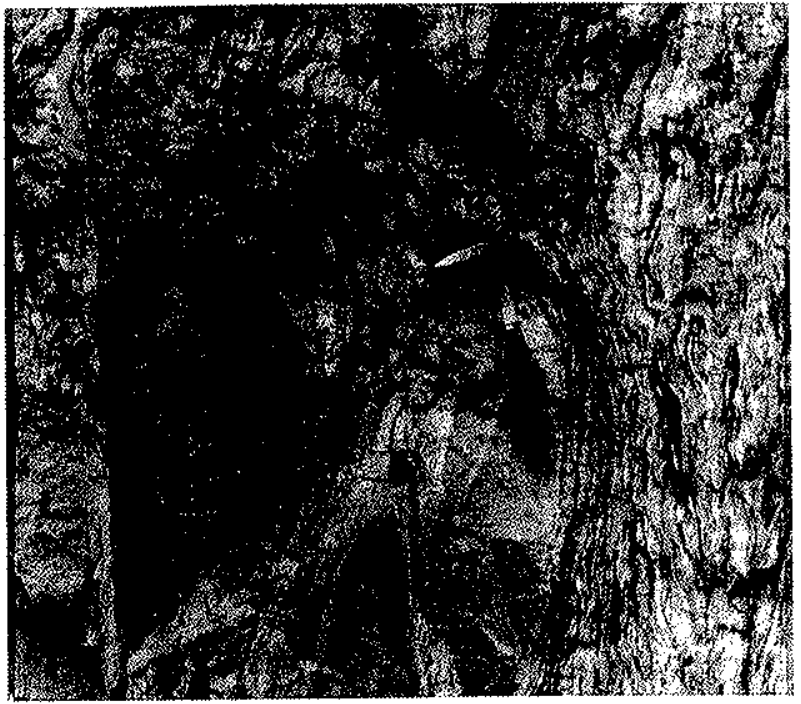

Foto 5 - Ponto 53. Migmatito cinzento com estrutura flebitica e schlieren, incluindo xenólitos ou boudins de rocha cálcio-silicática de granulação fina 
Assim, nesses migmatitos, é possível reconhecer duas fases importantes de cataclase e recristalização ligadas com toda certeza a dois eventos importantes de deformação, praticamente concordantes e superimpostos.

Os porfiroclastos mais comuns continuam sendo de plagioclásio (andesina), comumente antipertítico, e d̀s vezes saussuritizado, ortoclásio pertítico e mais raramente hornblenda ou ortopiroxênio. Nos tipos mais recristalizados, com microclínio na matriz, o quartzo perde o aspecto deformado, alinhando-se em cordðes de gräos reajustados e mais límpidos, que separam as faixas granoblásticas, em que os grãos exibem contatos de equilíbrio.

Cabe ressaitar ainda para os migmatitos a grande riqueza em biotita apresentada por alguns tipos em que esse mineral, em amostras de granulação média a grossa, chega a constituir cerca de $30 \%$ a $40 \%$ em volume dessas amostras, fato que as torna friáveis, mesmo quando frescas. A presença de granada também é comum.

A passagem da unidade litológica 3 para as rochas da unidade de gnaisses e granulitos bandados, que ocorre logo ao sul, faz-se gradativamente à medida que as estruturas em bandas ou faixas de atitude, em geral vertical, vão-se tornando mais notáveis.

O aspecto mais marcante das rochas da unidade 4 é a estrutura fina e regularmente bandada ou fitada, que exibem, onde se intercalam sucessivamente bandas de espessura em geral centimétricas (variam de milimétrica a muitos metros), de composição e cores diversas: de brancas, compostas só de quartzo e feldspato, passando pelos tons esverdeados dos charnockitos, a pretas ricas em hornblenda e piroxênio (Fotos 3 e 6). A origem dessas estruturas tem sido sempre considerada, pelos vários autores que estudaram a área, como a preservação da estratificação de antigo pacote sedimentar, apesar do alto grau metamórfico das recristalizaçס̃es e da forte deformação a que estiveram submetidas (Rosier, 1957 e 1965; Delhal et al., 1969).

A presença de niveis metassedimentares não pode ser contestada, pois várias intercalações de quartzitos, calcários e rochas cálcio-silicáticas têm sido registradas e são indicadas nos diversos mapas geológicos dessa região. No entanto, a expressão em superfície dessas intercalaçðes é reduzida e nos parece que boa parte dos gnaisses e granulitos tem origem magmática. A heterogeneidade desse pacote rochoso, realçada atualmente por sua notável estrutura bandada, é consequência de um processo de fortes deformaçðes e redobramentos, que colocou lado a lado litologias as mais diversas e nas mais variadas escalas, de rochas charnockíticas de catazona a metassedimentos, e gnaisses quartzo-feldspáticos supracrustais de fácies anfibolito, transformando esses materiais em blastomilonitos. Assim, interpretamos a estrutura bandada e fitada atual das rochas da Faixa Paraíba do Sul, onde as mesmas litologias se repetem sucessivamente, como o resultado de intenso processo tectônico para o qual já chamamos a atenção nas páginas anteriores. A sequiencia das Fotos 2 e 3 ilustra esse processo.

A intensidade do processo de dobramento foi tal na região que as estruturas de transposição resultantes apresentam expressiva regularidade, observando-se, porém, nos afloramentos, interrupçðes na continuidade dos leitos. Os ápices das dobras muito raramente são preservados, necessitando certo cuidado para ser reconhecidos. Esse fato é ilustrado pelo afloramento 2 (Foto 7), no qual se observam dobras intrafoliais disruptas. Quando encontradas, as dobras são muito cerradas e predominantemente do tipo isoclinal, em geral anisópacas com planos axiais verticais e eixos subhorizontais. Podem ser tão diminutas que só é possivel observá-las ao microscópio (Fotomicrografia 6 ).

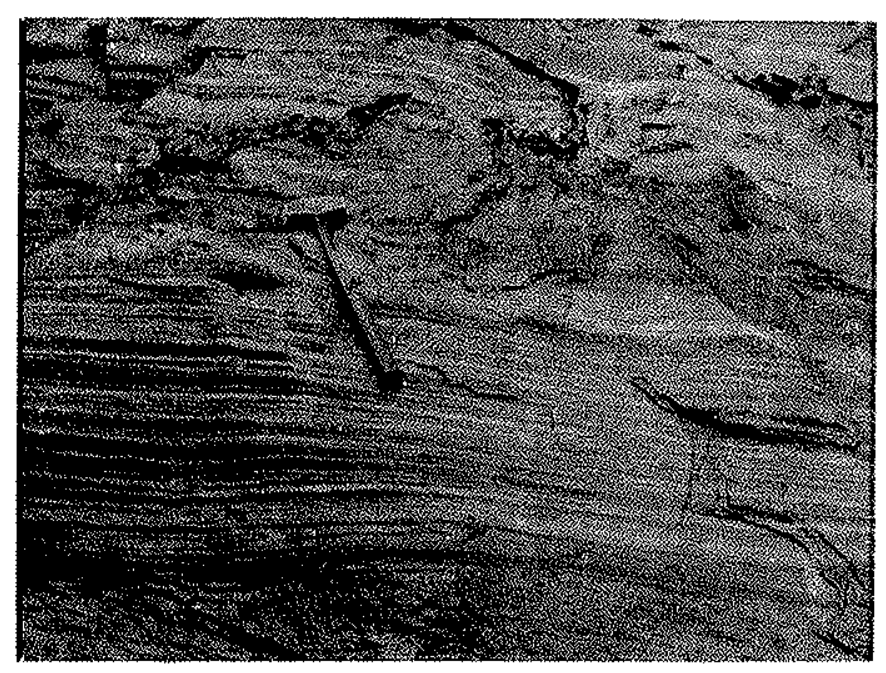

Foto 6 - Ponto 36. Blastomilonito bandado exibindo foliação de transposição bastante regular

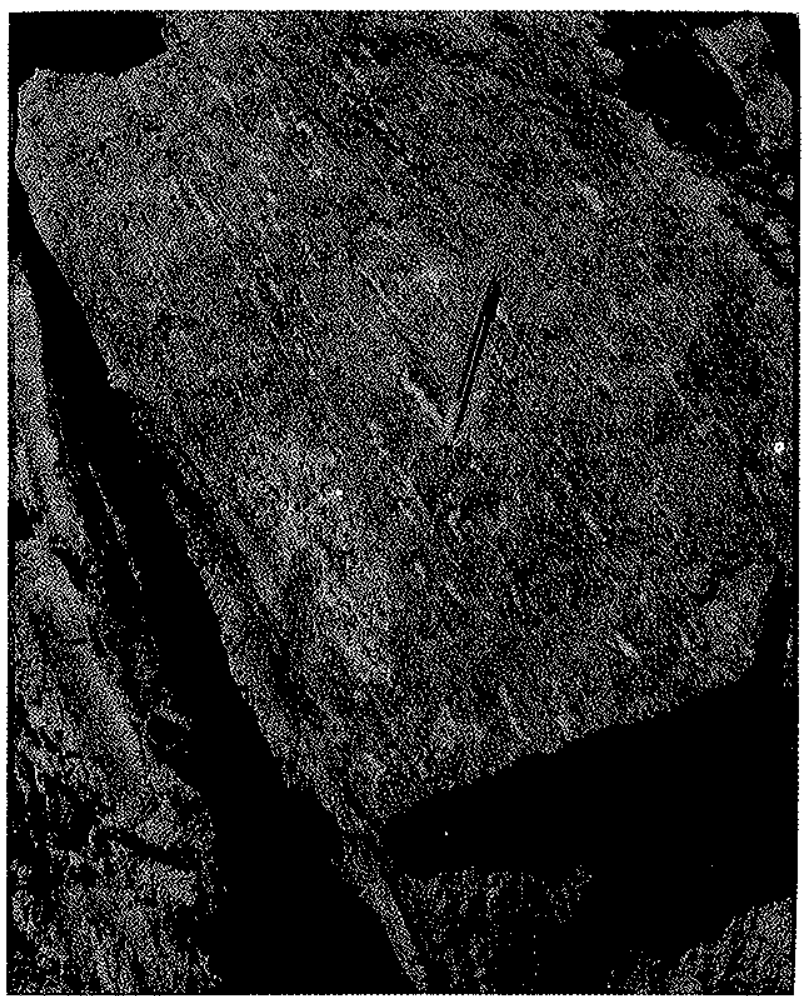

Foto 7 - Ponto 2. Migmatito cinzento mostrando dobras intrafoliais rompidas

Outro aspecto notável que resulta da forte deformação é o aparecimento de boudins, principalmente de anfibolito, ou de estruturas tipo oftalmítica, em que os elementos ocelares (augen) são representados por hornblenda, feldspato potássico pertítico, plagioclásio e mais raramente piroxênios.

Gnaisses quartzo-feldspáticos são tipos litológicos muito comuns na Faixa Paraíba do Sul. Compoem-se de quartzo, plagioclásio tipo oligoclásio-andesina, feldspato potássico que pode ser ortoclásio pertítico ou microclínio, biotita e granada. As texturas são sempre blastomiloníticas com a recristalização variando nas diversas intercalaçðes. Nos tipos menos cristalizados observam-se ainda muitos porfiroclastos de plagioclásio saussuritizado e ortoclásio, e, na matriz, recristalizam esses feldspatos, mais quartzo e biotita. Quartzo 
constitui também cordðes que conferem foliação às amostras e separam os leitos granoblásticos (Fotomicrografia 4). Esses cordðes exibem muitas vezes dobras microscópicas semelhantes às observadas no afloramento 2 (Foto 7). 0 aparecimento de microclínio na matriz granoblástica marca nova fase de recristalização que prosseguiu além da deformação. Esse mineral desenvolve-se tanto no mosaico equilibrado granoblástico como em cristais maiores, quase porfiroblásticos. O quartzo também acompanha o processo, constituindo já massas mais arredondadas que isolam os cordðes orientados da fase anterior. Os porfiroclastos tornam-se muito raros. Nessas condições, essas rochas assumem aspecto de gnaisses granitóides.

As rochas charnockíticas, que aparecem com pouca frequêencia ao longo do vale do Rio Paraíba do Sul e se tornam muito abundantes quando infletimos em direção a Itaperuna, são mais refratárias a essa última fase de recristalização e raramente exibem microclínio na matriz granoblástica. Os tipos petrográficos mais comuns são charnockitos e enderbitos, tendo sido registradas pequenas intercalaçðes de composição norítica. Os minerais característicos dessas variedades são ortoclásio pertítico (às vezes mesopertítico), plagioclásio tipo oligoclásio nos charnockitos e andesina nos enderbitos, ortopiroxênios principalmente hiperstênio, clinopiroxênios da série diopsídio-hedenbergita, hornblenda verde-parda e granada. A disposição textural primitiva desses minerais raramente é conservada, pois essas rochas se apresentam sempre intensamente deformadas, blastomiloniticas, com porfiroclastos ocelares corroídos e girados de hiperstênio, clinopiroxênio, plagioclásio antipertítico, ortoclásio pertítico e, às vezes, hornblenda marrom e granada (Fotomicrografia 5). Por efeito da deformação e da recristalização, essas rochas mostram sempre conspícua laminação milimétrica, destacando-se o quartzo, que assume formas lamelares ou lenticulares e é o principal responsável por seu aspecto foliado. Na matriz, desenvolvem-se pequenos indivíduos de feldspato potássico sem geminação, plagioclásio e quartzo, a partir da fragmentação dos grandes individuos primitivos. Nas intercalaçðes mais básicas, que ocorrem dentro dos tipos charnockíticos, orto e clinopiroxênios são mais abundantes além de hornblenda marrom. Constituem grandes cristais corroídos e deformados, com lamelas e traços de clivagem curvos, rođeados por hornblenda,

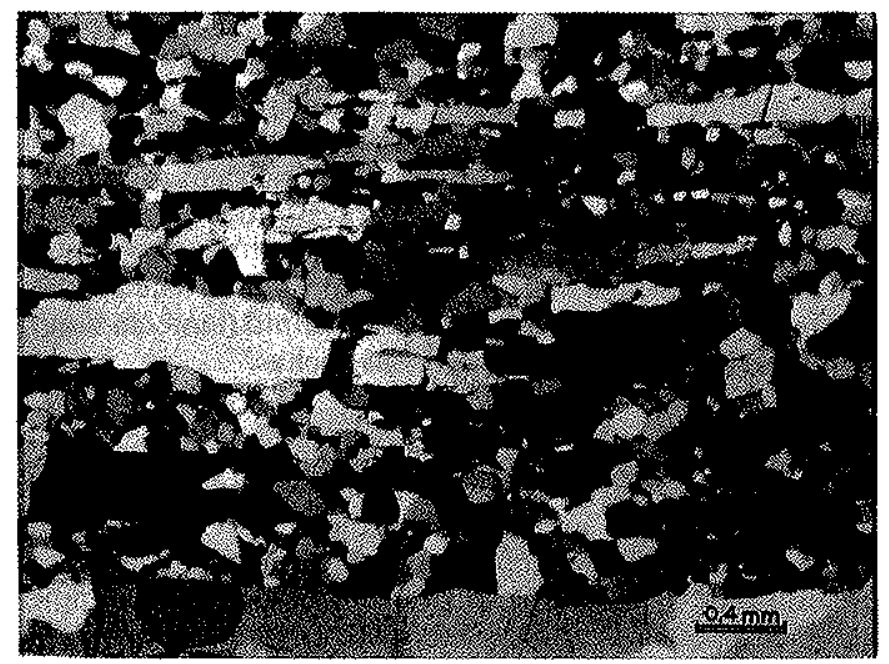

Fotomicrografia 4 - Amostra 10. Blastomilonito mostrando leitos de quartzo alongado, que separam mosaicos granoblásticos de composiça quartzo-feldspática. Nicois cruzados

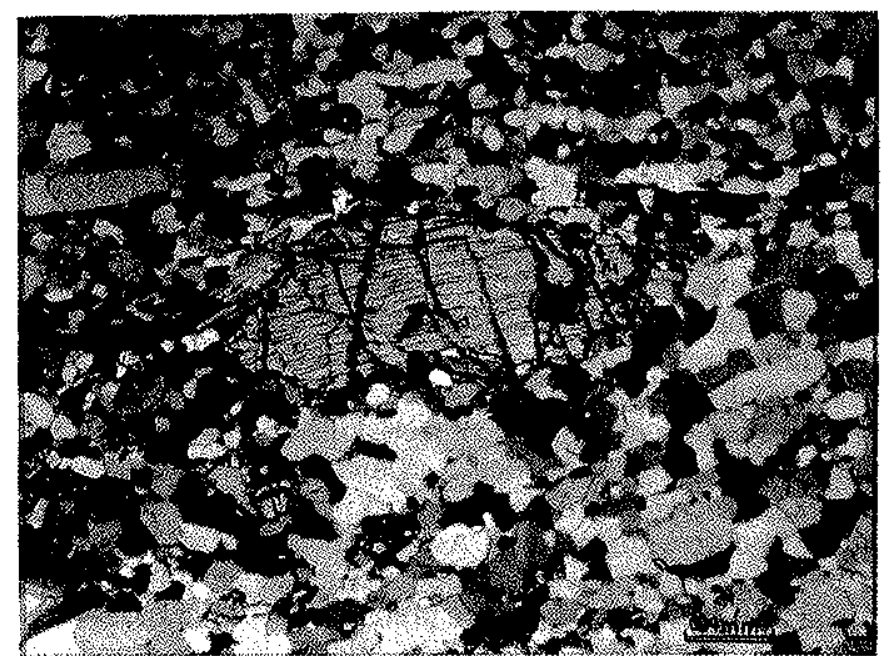

Fotomicrografia 5 - Amostra 10. Granulito blastomilonítico. Porfiroclastos de hiperstênio em mosaico granoblástico de quartzo, plagioclásio e biotita. Nicóis cruzados

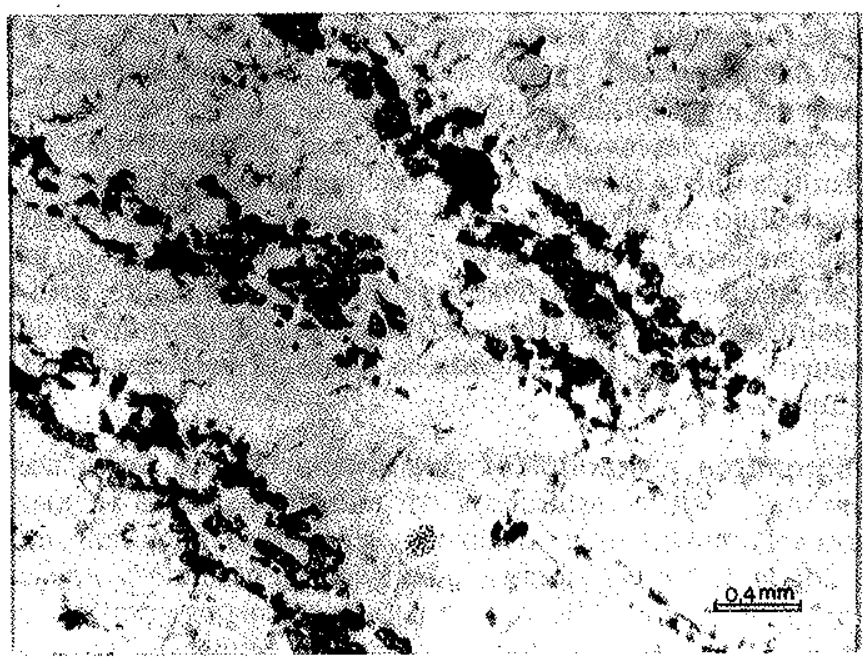

Fotomicrografia 6-Amostra 36-A. Blastomilonito quartzo-feldspático exibindo leito de granada dobrado. Nicóis paralelos

biotita ou filossilicatos fibrosos esverdeados, ou por pequenos grãos também corroídos e igualmente alterados. Næo há recristalização dos piroxênios na matriz, embora o processo de deformação deva ter ocorrido em condições de fácies anfibolito ou mesmo granulito, porém sem a presença de água, o que permitiu a preservação de orto e clinopiroxênios já existentes, sendo a redução da granulação a modificação mais marcante.

Para nordeste da região estudada, as rochas charnockíticas passam a predominar dentro da Faixa Paraiba, constituindo grandes massas mais homogêneas, exibindo feiçðes estruturais e texturais como as descritas para a Faixa Juiz de Fora.

Os tipos metassedimentares mais importantes, que aparecem inseridos nos gnaisses e granulitos da Faixa Paraiba, são quartzitos e mármores. Essas rochas constituem corpos que se destacam muito mais pela persistência longitudinal que pela espessura. Esta quase nunca ultrapassa algumas centenas de metros, ao passo que o comprimento dessas ocorrências, embora com interrupç̋̃es, pode atingir dezenas de quilômetros, como é bem indicado pelos trabalhos de 
Rosier (1957 e 1965) e no mapa geológico do Estado do Rio de Janeiro (1977). Os quartzitos mostram granulação fina e foliaçăo muito nítida, destacando-se pequenas quantidades de moscovita esverdeada. Os mármores, quando puros, constituem-se de calcita ou dolomita, e, quando silicosos, apresentam silicatos de cálcio e magnésio, tais como diopsídio, granada, clinozoisita, titanita e forsterita.

Dos fatos ora apresentados sobre o conjunto litolbgico Paraíba, devem ser destacados alguns pontos que parecem ser muito importantes para a compreensão final da origem dessas rochas. $O$ primeiro é estrutural e metamórfico, e refere-se às fases de deformação e recristalização que ocorreram nessa área e atingiram rochas já metamorfizadas nas condiçðes de fácies granulito (charnockitos e tipos associados) ou anfibolito (migmatito). As evidências dessas litologias mais antigas são indicadas pela presença das texturas porfiroclásticas (restando da rocha pretérita apenas grandes cristais corroídos, como hiperstênio, plagioclásio e ortoclásio pertítico), a presença de corpos lenticulares boudinados dessas litologias, dentro de gnaisses e migmatitos, bem como as intercalaçðes tectônicas que colocam lado a lado associaçðes de fácies metamórficas diferentes. Os piroxênios, minerais típicos das paragêneses de alto grau, não recristalizam na fase de formação das texturas granoblásticas e, na fase sucessiva de deformação e recristalização, tendem a desaparecer, cedendo lugar principalmente à biotita parda. Nessa fase derradeira, desenvolve-se um processo de transformação granítica que se inicia com o aparecimento da geminação de microclínio no ortoclásio e prossegue até que essas rochas assumam aspecto de gnaisses granitóides. Nesse processo, as intercalaçðes charnockíticas repetidas tectonicamente, principalmente nas imediaçðes de Três Rios, comportam-se de maneira refratária, mantendo-se assim preservadas dessa granitização.

Migmatitos e granitóides das imediaçōes da Serra dos Orgãos A recristalização de microclínio torna-se mais notável à medida que nos dirigimos para o sul da área, rumo à cidade de Nova Friburgo, adentrando a unidade litológica 5. $\mathrm{O}$ aparecimento de veios e pequenos corpos graníticos e pegmatíticos, comumente de coloração branca ou rosada, aspecto não muito abundante nas rochas da Faixa Paraíba do Sul, torna-se comum aqui, aumentando à medida que atingimos a Serra dos Órgãos, originando tipos migmatíticos. Á estrutura desses migmatitos também varia, passando de estromatítica mais característica junto às litologias Paraiba para tipos mais homogêneos, oftalmíticos, schlieren ou mesmo nebulíticos. A presença de boudins ou xenólitos de anfibolitos e rochas cálcio-silicáticas é registrada novamente como resultado dos processos estruturais que afetam a área, porém em menor quantidade. As porçð̃es mais escuras têm composição quartzo diorítica a diorítica e compōem-se essencialmente de plagioclásio (andesina), biotita parda e hornblenda verde-amarelada. Como testemunho de uma fase anterior a essa recristalização, encontram-se ainda raros porfiroclastos, em geral de plagioclásio, totalmente envolvidos por matriz granoblástica.

Faixa Serra dos Orgãos $\mathrm{O}$ aparecimento de pequenos corpos graníticos torna-se mais comum em meio às litologias de gnaisses granitóides e migmatitos, que vão gradativamente assumindo aspecto granítico. É a característica principal das rochas da Faixa Serra dos Orgãos que, segundo Delhal et al. (1969) e Cordani et al. (1973), são rochas singenéticas de caráter palingenético formadas no decorrer do último ciclo orogênico que afetou a região; são o produto de uma granitização difusa e incompleta de rochas mais antigas conservan- do relaçð̄es comuns: textura, zonação, direção e mergulho. A passagem gradativa das fácies migmatíticas para as fácies graníticas, chegando à formação de corpos graníticos póstectônicos, permite a suposição de que todo esse conjunto faz parte do mesmo processo petrogenético. Tudo ocorre sem que nenhuma discordância estrutural tenha sido registrada.

Migmatitos com estruturas bandadas ainda aparecem nessa última faixa, predominando, porém, os tipos nebuliticos. Delhal et al. (1969) consideram como paleossoma desses migmatitos as rochas do Grupo Paraíba do Sul (para eles, metassedimentos), que constituiram restos nåo-granitizados. Todavia, se levarmos em conta as observaçðes já apresentadas, veremos que existe mesmo a possibilidade de que os gnaisses granitóides correspondam à recristalização quase completa de rochas arqueanas, parcialmente modificadas no Ciclo Transamazônico. Assim, poderíamos admitir como válida a denominação de "arqueano mais ou menos palingenético" atribuída por Rosier (1957 e 1965) para as rochas da Serra dos Órgãos atingidas pela orogênese assíntica. De fato, considerando que a maior parte das litologias tidas como transamazônicas nada mais são que a transformação parcial das rochas arqueanas, envolvendo charnockitos e migmatitos, e que essa transformação é um processo contínuo, cuja evolução pode ser acompanhada desde as regiōes mais típicas do Arqueano, como de Barbacena até Nova Friburgo, é bastante razoável interpretarmos o conjunto litológico da Serra dos Orgãos como resultante da deformação e recristalização quase completa daquelas rochas.

Os efeitos do Ciclo Transamazônico, que podem ser ainda observados nos gnaisses granitóides e migmatitos, são registrados em alguns afloramentos pelas estruturas bandadas ou fitadas perfeitamente concordantes com as atitudes $\mathrm{Pa}$ raíba e nas amostras, pela presença de possíveis porfiroclastos de plagioclásio saussuritizados ou de pequenos trechos de textura blastomilonítica envolvidos por material granítico totalmente recristalizado. Em boa parte dos materiais analisados, porém, não há vestígios texturais de ciclos interme. diários.

Além dos migmatitos e gnaisses granitóides, fazem parte também desse conjunto litológico granitos normais e porfiróides, bem como pequenas intercalaçōes de gnaisses granatiferos com sillimanita, quartzitos, rochas cálcio-silicáticas e anfibolitos.

Sob o ponto de vista petrogenético, a presença de migmatitos dentro do conjunto litológico da Serra dos Órgãos não indica necessariamente um aporte de quartzo e feldspato mas, apenas, a intervenção de uma certa quantidade de água, considerando-se que eles resultam da transformação de fácies mais antigas (arqueanas ou transamazônicas) de composiçăo até certo ponto comparável. Pode-se, no entanto, supor que, no caso dos gnaisses granitóides e granitos, um aporte de álcalis mais ou menos importante tenha ocorrido, tendo em vista a riqueza em microclínio (também biotita e moscovita) apresentada por essas rochas.

ESTRUTURAS As principais feiçðes estruturais características dessa vasta área já foram abordadas, à medida que se descreviam as unidades litológicas. Os dados disponíveis são ainda poucos e dispersos para se fazer a síntese estrutural de uma região de evolução geológica tão complexa. Dados estruturais obtidos nas proximidades de Três Rios são disponíveis também no trabalho de Campanha (1981).

O estilo tectônico é o mesmo para todos os conjuntos de rochas estudadas, observando-se em toda a área várias fases 
de dobramento. As fases de dobramento têm vergência concordante para noroeste em direção ao Cráton do São Francisco, fato já mencionado por Almeida (1977), e produzem dobras muito cerradas do tipo isoclinal anisópaco. A foliação resultante é plano-axial e provém da transposição de foliação ou bandamento anterior. Os eixos dessas dobras são predominantemente sub-horizontais com direçðes médias este-nordeste. A foliação ou bandamento mergulha para norte nos gnaisses e migmatitos da Serra dos Órgåos, é vertical nos gnaisses e granulitos do Paraíba do Sul e cai predominantemente para sul na faixa charnockítica de Juiz de Fora. Esse estilo tectônico é bastante favorável ao desenvolvimento de grandes falhas de empurrão bem como à formação de estruturas do tipo nappe, fato já levantado por Rosier (1957 e 1965), embora o esquema geral apresentado por esse autor necessite de mais dados para comprovação.

Ainda como consequêencia dessas duas fases de dobramento superpostos, desenvolvem-se em toda a área estruturas de boudinage levando d̀ formação de corpos elipsóides (boudins) dos mais variados tamanhos e composiçoes, predominando os tipos anfibolíticos e cálcio-silicáticos. Desenvolvem-se também extensas faixas de blastomilonitos, sendo que a principal corresponde ao alinhamento do vale do Rio Paraíba do Sul, notável feição estrutural que se alonga por mais de duas centenas de quilômetros e que recebeu a denominação de Lineamento de Além-Paraíba por Almeida et al. (1975). Segundo Campanha (1981), é possível admitir-se uma evolução polifásica para essa estrutura tendo em vista que as rochas granulíticas exibem feiçőes superimpostas, tais como deformação cataclástica, recristalização, dobramento, transposição e migmatização incipiente. No final do Brasiliano, movimentos transcorrentes teriam reativado esse lineamento, sendo os últimos deslocamentos de caráter normal ligados provavelmente às intrusões básicas e alcalinas do meso-cenozóico.

$\mathrm{Na}$ porção sul da área, dentro do domínio da Serra dos Órgãos, os processos de recristalização são tão intensos, produzindo rochas granitóides, que as evidências estruturais do forte dobramento e das transposições ficam mascaradas. Os produtos resultantes são gnaisses granitóides e migmatitos normais, que raras vezes deixam transparecer os efeitos das deformaç̋es por que passaram.

Uma outra fase de dobramento é ortogonal, e posterior às mencionadas, e produz dobras abertas de amplitudes variáveis, cujos eixos têm direção noroeste.

CONSIDERAÇŌEs finAis A Faixa Paraíba do Sul, situada dentro do cinturão granulítico Atlântico (Wernick et al., 1979), é constituída por um conjunto de rochas metamórficas nas quais se sobressaem migmatitos, gnaisses, granulitos e rochas charnockíticas. Polimetamorfismo é característica marcante dessa região e pelo menos três ciclos superpostos são registrados: Jequié de $2800 \mathrm{~m}$.a., Transamazônico de 2000 m.a. e Brasiliano de 600 m.a.

De idade arqueana são os migmatitos bandados e dobrados com abundantes encraves de rochas básicas que ocorrem ao norte de Juiz de Fora bem como os granulitos e rochas charnockíticas que constituem extensas zonas alongadas distribuídas principalmente ao norte do Rio Paraíba do Sul. A razão isotópica $\mathrm{Sr}^{87} / \mathrm{Sr}^{86}$ de 0,706 para essas rochas indica vida crustal prolongada e permite supor idades primárias superiores a $2800 \mathrm{~m}$.a.

O Ciclo Transamazônico deixou seu registro nas rochas regionais já existentes através de fortes deformaçð̄es e recristalizaçōes, transformando esses materiais em blastomilonitos e gerando novas foliações de transposição. Não há evidências de formação de rochas de alto grau nessa época, tendo o metamorfismo atingido as condiçōes mais elevadas da fácies anfibolito.

O Ciclo Brasiliano atinge a área de maneira generalizada, marcado pela recristalizaçăo do microclínio, formação de migmatitos e de rochas granitóides sintectônicas e mais raramente pós-tectônicas. Seus efeitos fazem-se sentir principalmente sobre rochas gnáissicas e migmatíticas mais antigas, mostrando-se os granulitos rẹfratários a sua ação e preservando-se como paleossoma desses migmatitos ou na forma de boudins e xenólitos.

As tendências geoquímicas gerais (Oliveira, 1980 e 1982) são muito semelhantes para rochas dos três ciclos, principalmente quanto aos elementos maiores. Os diagramas de variação revelam para os conjuntos litológicos estudados comportamento comparável ao das rochas ígneas calco-alcalinas, sugerindo que boa parte desses materiais tem origem magmática.

As rochas charnockíticas também exibem esse comportamento, diferindo das demais quanto aos elementos $\mathrm{K}, \mathrm{Rb}, \mathrm{Sr}$ e suas razões, que fogem aos padrões normais de concentração na crosta. A razão $\mathrm{K} / \mathrm{Rb}$ relativamente elevada dessas rochas é feição primária adquirida por ocasião do metamorfismo catazonal (Oliveira, 1982).

Os valores de temperatura calculados por Oliveira (1981), a partir da coexistência de orto e clinopiroxênios nos granulitos, situam-se aproximadamente entre $850^{\circ} \mathrm{C} \mathrm{e} 880^{\circ} \mathrm{C}$, com pressões totais inferiores a $8 \mathrm{~kb}$. Esses valores coadunam-se com a classificação dessas rochas dentro da fácies granulito e permitem supor que durante o metamorfismo as reaçðes de "charnokitização" levaram ao aparecimento de líquidos anatéticos que seriam retirados do sistema, provocando recristalização de tipos petrográficos mais "secos" e empobrecidos nesse elemento e em $\mathrm{Rb}$. Os valores de $\mathrm{T}$ foram suficientemente altos para provocar anatéxis, mesmo nas fases menos hidratadas, gerando migmatitos "secos", onde mobilizados charnockíticos envolvem tipos mais básicos enderbíticos.

As condiçðes de pressão e temperatura, atingidas durante o processo metamórfico que culminou com a formação das rochas de alto grau, permitem estimar em $30 \mathrm{~km}$ a profundidade em que tal processo ocorreu. Com isso pode-se inferir um gradiente geotérmico entre $30^{\circ} \mathrm{C}$ e $35^{\circ} \mathrm{C} / \mathrm{km}$ para o $\mathrm{Ar}$ queano nessa região.

As feiçðes texturais primárias exibidas por muitas amostras de granulitos, juntamente com as tendências calco-alcalinas e as fortes correlações demonstradas por alguns elementos, como Fe, Mn e Ti (Oliveira, 1980 e 1982), levam-nos a admitir, adotando-se o modelo proposto por Tarney et al. (1977), que a grande maioria das litologias de fácies granulito se originou no Arqueano a partir de processo envolvendo inicialmente extenso magmatismo granodiorítico-tonalítico, que atingiu seu ponto máximo com o metamorfismo catazonal. As profundidades em que ocorreram essas transforma. çóes permitem supor uma closta arqueana já muito espessa.

A evolução geológica dessa faixa a partir de então segue os esquemas idealizados para os cinturōes móveis, superpondo-se eventos de deformação com grandes empurroes, transcorrências, intensa migmatização e granitogênese.

Agradecimentos $O$ apoio financeiro para realização do presente trabalho foi obtido junto ao Conselho Nacional de Desenvolvimento Científico e Tecnológico (CNPq). Aos Drs. Jacques Delhal, do Musée Royal de l'Afrique Centrale, e Umberto G. Cordani nossos agradecimentos por facilitarem os dados disponiveis sobre a região. 


\section{BIBLIOGRAFIA}

ALMEIDA, F. F. M. de - 1977 - O Cráton do Såo Francisco. Rev. Bras. Geoc. 7(4):349-364

ALMEIDA, F. F. M. de, HASUI, Y. e CARNEIRO, C. D. R. $-1975-$ O Lineamento de Além-Paraiba. An. Acad. Bras. Ciênc. 47:575.

BARAGAR, W. R. A. e GOODWIN, A. H. - $1969-$ Andesites and Archaean volcanism of the Canadian Schield. Bull. Dept. Geol. Min. Resources, State of Oregon, 65:121-142.

CAMPANHA, G. A. C. - 1981 - O Lineamento de Além-Paraíba na área de Três Rios (RJ). Rev. Bras. Geoc. 11(3):159-171.

CORDANI, U. G., DELHAL, J. e LEDENT, D. - 1973 - Orogèneses superposées dans le Précambrien du Brésil sud-oriental (Etats de Rio de Janeiro et de Minas Gerais). Rev. Bras. Geoc. 3(1):1-22.

COSTA, L. A. M. e MACHETTO, C. M. L. - 1978 - Evoluçăo textural dos granulitos de São Fidélis, RJ. An. XXX Congr. Bras. Geol. 3:1250-1264, Recife.

DELHAL, J., LEDENT, D. e CORDANI, U. G. - $1969-$ Ages Pb/U, $\mathrm{Sr} / \mathrm{Rb}$ et $\mathrm{Ar} / \mathrm{K}$ de formations métamorphiques du Sud-Est du Brésil (Etats de Rio de Janeiro et de Minas Gerais). An. Soc Geol. Belg. 92:271-283.

DRURY, S. A. - 1973 - The geochemistry of Precambrian granulite facies rocks from Lewisian Complex of Tiree, Inner Hebrides. Scotland Chem. Geol. 11:167-188.

EBERT, H. - 1957 - Beitrag zur Gleiderung des Prakambriums in Minas Gerais. Geol. Rundschau 453:471-521.

FONSECA, M. J. G. et $a l$. $-1978-$ Folhas Rio de Janeiro/Vitoria/Iguape. Carta Geológica do Brasil ao Milionésimo. Dep. Nac. Prod. Min. Brasilia.

HASUI, Y e OLIVEIRA, M. A. F de - no prelo - Provincia Mantiqueira. In: O Pré-Cambriano do Brasil (F. F. M. de Almeida e Y. Hasui, coordenatlores). Ed. Edgard Bfucher Ltda.

NORRISH, K. e HUT'TON, J. T. - 1969 - An accurate X Ray spectrographic method for the analysis of a wide range of geological samples. Geochim. Cosmochim. Acta 33:431-453.

OLIVEIRA, J. A. D. de et al. - 1977 - Mapa Geológico do Rio de Janeiro. Convênio Dep. Rec. Min. do Rio de Janeiro e Inst. Pesq. Espaciais. Niterói.
OLIVEIRA, M. A. F. de - 1980 - Petrologia das rochas granuliticas da Faixa Parafba do Sul, Estados do Rio de Janeiro e Minas Gerais. Tese ao Inst. Geoc. Ci. Exatas, Univ. Est. Paulista. Rio Claro, SP.

OLIVEIRA, M. A. F. de - 1981 - Granulitos da Faixa Paraiba do Sul: caracteres químicos dos piroxênios e valores geotermométricos. Rev. Bras. Geoc. 11(4):222-226.

OLIVEIRA, M. A. F. de - 1982 - Bulk geochemistry of the Paraiba do Sul granulitic belt. Rev. Bras. Geoc. 12(1-3):369-374.

ROSIER, G. F. - 1957 - A geologia da Serra do Mar entre os Picos de Ma ria Comprida e do Desengano. Bol. Div. Geol. Min., Dep. Nac. Prod. Min., (166): 1-58.

ROSIER, G. F. - 1965 - Pesquisas geológicas na parte oriental do Estado do Rio de Janeiro e na parte vizinha do Estado de Minas Gerais. Bol. Div. Geol. Min., Dep. Nac. Prod. Min. (222):1-41.

SHERATON, J. W. - 1970 - The origin of the Lewisian gneisses of North west Scotland, with particular reference to the Drumbeg area, Sutherland. Earth Planet. Sci. Letters 8:301-310.

SIGHINOLFI, G. P. - 1971 - Investigations into deep crustal levels: fractionating effects and geochemical trends related to high grade metamor phism. Geochim. Cosmochi. Acta 35:1005-1021.

STRECKEISEN, A. - 1974 - How should charnockitic rocks be named. In: Geologie des domaines cristallins, pp. 349-360, Soc. Geol. Belg.

TARNEY, J. e WINDLEY, B. F. - 1977 - Chemistry thermal gradients and evolution of the lower continental crust. $J$. Geol. Soc. London 134:153-172.

WERNICK, E. e ALMEIDA, F. F. M. de -1979 me geotectonic environments of Early Precambrian granulites in Brazil. Precambrian Re search 8:1-17.

WRIGHT, A. E., TARNEY, J., PALMER, K. F., MOORLOSCK, B. S. P e SKINNER, A. C. - 1973 - The geology of the Angmagssalik area East Greenland and possible relationships with the Lewisian of Scotland. In: The Early Precambrian of Scotland and related rocks of Greenland, Univ. Keele, p. 157-177.

MANUSCRITO

Recebido em 4 de abril de 1983 Revisão aceita em 7 de julho de 1983 